train from Manchester, that I had crossed London, that I had reached Guildford by a weary Sunday train from Waterloo, and that I had just eaten an enormous lunch. I panted and struggled half a pace behind him. I became stupendously hot. I made unexpected and unathletic sounds, like a man who is being smothered. Blissfully unconscious of all this was Shaw. . . . I wonder? . . . No; blissfully conscious of all this was Shaw.

\title{
Hero Worship
}

\section{ROBERT LORAINE}

From Winifred Loraine, Robert Loraine: Soldier, Actor, Airman (London: Collins, 1938) pp. 81-2. The following extract joins diary entries written by Robert Loraine in the summer of 1905 after his first meeting with Shaw at a matinee of Man and Superman at the Court Theatre, and after a visit to the Shaws' rented country house near Welwyn a few days later.

He has sharp bright-blue penetrating seer's eyes, ... . with the impish twinkle of a schoolboy. A transparent delicate alabaster skin, which gives him the appearance of being not at all of common clay, but having the minimum of earth and maximum of fire in his composition. A lightning conductor, a visitant, who makes other men look not so clean nor fresh as he.

I had expected his voice to have reverberations of the thunder, but it is high-pitched, clear and flexible as a violin's. He says: 'In a minute', not 'in a minnit', and speaks with the most persuasive variant of English I have ever heard, a satin-Irish brogue. . . . his wit and wisdom seem to me to be like the fresh and uncontaminated outlook on life of a baby, miraculously made supremely articulate. . . . [sic] I have a foolish selfassertive independence which fights against the idea of hero-worship, yet I was never free from the impression when Shaw was speaking to me that he might at any moment ascend to Heaven like Elisha on a chariot of fire.

As he walked back with me to the station a yokel called out: 'Hallo, Ginger Whiskers!' - at him. I could have thrashed the boy for his impudence - it seemed like sacrilege - but Shaw prevented me. 